\section{Selection of Eucalyptus grandis families across contrasting environmental conditions}

\author{
Paulo Henrique Müller da Silva ${ }^{1,2^{*}}$, Martin Marco ${ }^{3}$, Clayton \\ Alcarde Alvares ${ }^{1}$, David Lee ${ }^{4}$, Mario Luiz Teixeira de Moraes $^{5}$ \\ and Rinaldo Cesar de Paula ${ }^{6}$
}

\begin{abstract}
The objective was to select productive and stable E. grandis families across contrasting sites in Brazil and Uruguay. Survival and growth of 130 open pollinated families were evaluated three years after planting. Survival ranged from 28 to $89 \%$ and mean annual increment from 20.5 to $48.4 \mathrm{~m}^{3} \mathrm{ha}^{-1} \mathrm{y}^{-1}$. Low productivity in one site was attributed to unusually low rainfall and in the other, because of Cylindrocladium leaf disease. Heritability among families and the correlation family by environment were intermediate. Genetic pairwise correlations ranged from 0.03 to 0.81 across sites. The lowest genetic correlation between sites was observed where Cylindrocladium leaf disease occurs. Selection of top families across sites allowed selecting the best ones in each site. However, the effect of genotype-environment interactions was observed where climatic conditions are not adequate to the E. grandis, favoring the occurrence of Cylindrocladium disease.
\end{abstract}

Keywords: GEI, biotic and abiotic stress, productivity, adaptability, ecological zoning.

\section{INTRODUCTION}

Eucalyptus grandis W. Hill ex Maiden (Flooded or Rose gum) is one of the most important species in tropical and subtropical environments. As a pure species or as parent of hybrid varieties, E. grandis can reach high productivity in suitable sites and produce timber with amenable properties to a wide range of uses (Denison and Kietzka 1993, Silva et al. 2013). E. grandis is among the group of "big nine" related species of subgenus Symphyomyrtus identified by Harwood (2011) that, along with its interspecific hybrids, account for around $90 \%$ of the world's eucalypt plantation resources across 90 countries (Silva et al. 2016a).

E. grandis has two contiguous occurrences with several disjunctions in its distribution in Australia. In the South, it occurs on coastal and sub-coastal ranges from near Bundaberg, Queensland-QLD (lat $25^{\circ} 19^{\prime} \mathrm{S}$, long $151^{\circ} 55^{\prime} \mathrm{E}$, and alt $130 \mathrm{~m}$ asl) to near Newcastle, New South Wales-NSW (lat $32^{\circ} 55^{\prime}$ S, long $151^{\circ} 46^{\prime}$ $\mathrm{E}$, and alt $10 \mathrm{~m}$ asl). In the North, it occurs in QLD from the Windsor Tableland west of Daintree (lat $16^{\circ} 15^{\prime} \mathrm{S}$, long $145^{\circ} 24^{\prime} \mathrm{E}$, and alt $1100 \mathrm{~m}$ asl) to near Paluma (lat $18^{\circ} 25^{\prime} \mathrm{S}$, long $146^{\circ} 15^{\prime} \mathrm{E}$, and alt $850 \mathrm{~m}$ asl) and extends down to altitudes of only $400 \mathrm{~m}$ around Copperlode Dam (around lat $16^{\circ} 59^{\prime} \mathrm{S}$, long $145^{\circ}$ $40^{\prime} \mathrm{E}$ ) on flat and lower slopes (Brooker and Kleinig 2004, Boland et al. 2006).
Crop Breeding and Applied Biotechnology 19: 47-54, 2019 Brazilian Society of Plant Breeding. Printed in Brazil http://dx.doi.org/10.1590/198470332019v19n1a07

\footnotetext{
*Corresponding author: E-mail: paulohenrique@ipef.br (D) ORCID: 0000-0002-2926-8719
}

Received: 13 August 2018 Accepted: 18 December 2018

${ }^{1}$ Instituto de Pesquisas e Estudos Florestais, 13.415-000, Piracicaba, SP, Brazil

2 Universidade Estadual Paulista, 18.603-970, Botucatu, SP, Brazil

${ }^{3}$ Estación Experimental Agropecuaria Concordia, C.C. No 34, E3200AQK, Concordia, Entre Ríos, Argentina

${ }^{4}$ University of the Sunshine Coast, Forest Industries Research Centre, Maroochydore DC 4558, Queensland, Australia

${ }^{5}$ Universidade Estadual Paulista, 15.385-000, Ilha Solteira, SP, Brazil

${ }^{6}$ Universidade Estadual Paulista, 14.884-900, Jaboticabal, SP, Brazil 
E. grandis is an important species of commercial forest plantations and thus has been subject to genetic improvement programs for many decades in several countries, e.g. South Africa (van Wyk 1976), Australia (Burgess et al. 1996), Brazil (Ferreira 2015), Sri Lanka (Bandara and Arnold 2017) with improvements in generations by recurrent selection and open pollinated breeding. However, the species is susceptible to several diseases in some environmental conditions, namely Cryphonectria cubensis (eucalypt canker); Cylindrocladium leaf blight; and Astropuccinia psidii (eucalypt rust) (Conradie et al. 1992, Rodas et al. 2005, Silva et al. 2013, Alvares et al. 2016). Hybridization, particularly with E. urophylla and $E$. camaldulensis, has allowed the development of successful commercial plantation varieties in environments where $E$. grandis, as a pure species, is not well adapted (Brawner et al. 2011, Campoe et al. 2016).

Eucalypt breeding programs have focused on genotype selection through within and between species variability to ensure the best germplasm for plantation establishment (Gapare et al. 2003, Miranda et al. 2013, Bandara and Arnold 2017). Genetic variability is essential, not only for advancing genetic gain, but also as a buffer for various threats, such as pests, diseases and climate change (Jurskis 2005, Wingfield et al. 2008, Brawner et al. 2013).

In Brazil, Edmundo Navarro de Andrade introduced E. grandis at least a hundred years ago in Rio Claro Experimental Station; however, it was only in 1970 when provenance and recurrent selection of open pollinated seed orchard was intensified by various institutions. Provenances from around Coffs Harbour exhibited the greatest growth potential in the state of São Paulo, where subtropical conditions prevail (Ferreira 2015). However, Eldridge et al. (1993) reported that $E$. grandis from the Atherton region consistently display better disease tolerance than that of NSW provenances in tropical and subtropical environments.

The estimation of genetic parameters and breeding values are complex when calculated from trials on different sites, due to genotype by environment interactions (GEI). GEI evaluation allows breeders to identify genotypes performing well across the environment and select specific genotypes for each environment (Van Buijtenen 1992). GEI can occur as no crossover or crossover interaction (Acquaah 2007). If no crossover interactions are detected, then a single site may be used to select families for deployment across all sites. To handle heterogeneity of variances in environment correlations, evaluation needs to be properly carried out by a mixed model (Malosetti et al. 2013).

This study tests the selection of stable and productive $E$. grandis families, three years after planting, across divergent environmental conditions in South America.

\section{MATERIAL AND METHODS}

The study included up to 130 open-pollinated E. grandis families from five seed orchards (Table 1). The germplasm belongs to the Genetic Improvement Cooperative Program (PCMF) of Institute of Forestry Research and Studies (Instituto de Pesquisas e Estudos Florestais - IPEF). The trials were planted between May and December 2012 across four sites in Brazil and Uruguay (Figure 1).

The experimental layout was a randomized complete block design of four to six replicates with contiguous five-tree line plots planted across each of the four trials. The number of open pollinated families ranged from 114 to 130 per trial. As the trials were planted on land that belongs to forest companies (Figure 1), the routine tree stocking (spacing) and plantation management system of the company was used. Before planting, all sites were deep ripped to at least $45 \mathrm{~cm}$ and lime were applied (total area). All sites were fertilized using the standard fertilization regime and the seedlings were

Table 1. Climatic conditions of seed sources, origin and number of breeding generations

\begin{tabular}{|c|c|c|c|c|c|c|c|}
\hline \multirow{2}{*}{\multicolumn{2}{|c|}{ Seed Source }} & \multicolumn{3}{|c|}{ Climatic Classification } & \multirow{3}{*}{$\begin{array}{c}\text { Origin } \\
\text { Unknown }\end{array}$} & \multirow{3}{*}{$\begin{array}{c}\text { Generation } \\
\text { SPA } 1^{\text {st }}\end{array}$} & \multirow{3}{*}{$\begin{array}{c}\text { Number of families } \\
18\end{array}$} \\
\hline & & \multirow{2}{*}{$\begin{array}{c}\text { Rainfall }(\mathrm{mm}) \\
1294\end{array}$} & \multirow{2}{*}{$\begin{array}{c}\text { AAT }\left({ }^{\circ} \mathrm{C}\right) \\
20.3\end{array}$} & \multirow{2}{*}{$\begin{array}{c}\text { Koppen } \\
\text { Cwa }\end{array}$} & & & \\
\hline 1 & Rio Claro-SP, BR & & & & & & \\
\hline 3 & Tres Bocas-Rio Negro, UR & 991 & 17.6 & $\mathrm{Cfa}$ & Various & $\mathrm{SSO} 2^{\text {nd }}$ and $3^{\text {rd }}$ & 16 \\
\hline 4 & Concordia, AR & 1278 & 18.6 & $\mathrm{Cfa}$ & Various & $\mathrm{SSO} 2^{\text {nd }}$ and $3^{\text {rd }}$ & 64 \\
\hline 5 & Anhembi-SP, BR & 1237 & 20.8 & Aw/Cwa & Coffs Harbour & $\mathrm{SSO} 3^{\text {rd }}$ & 22 \\
\hline
\end{tabular}

SPA = seed production area, $\mathrm{SSO}=$ seedling seed orchard, $\mathrm{AAT}$ = annual average temperature 
irrigated with 3 to $4 \mathrm{~L}$ tree ${ }^{-1}$ at planting. Leaf cutter ant control (using baits) was applied and weeds were controlled by herbicide application until crown closure was reached.

Traits evaluated across all sites included survival, diameter at breast height (DBH), and height $(\mathrm{H})$ of trees at 3.14 to 3.59 years after planting. $\mathrm{DBH}$ and $\mathrm{H}$ were used to calculate the mean annual increment (MAI), using a stem factor $(f)$ of 0.45 and the total trial area $(T A)$ for each experiment.

$$
V_{\text {ol }} \text { ind }=\frac{\pi \cdot(D B H)^{2} \cdot H \cdot f}{4} \quad M A I=\frac{\Sigma V_{\text {ol }} \text { ind }}{T A \cdot \text { age }}
$$

DBH data were analyzed separately for each site (individual analyses) and the joint analysis using a linear mixed model analysis, as described by Resende (2016).

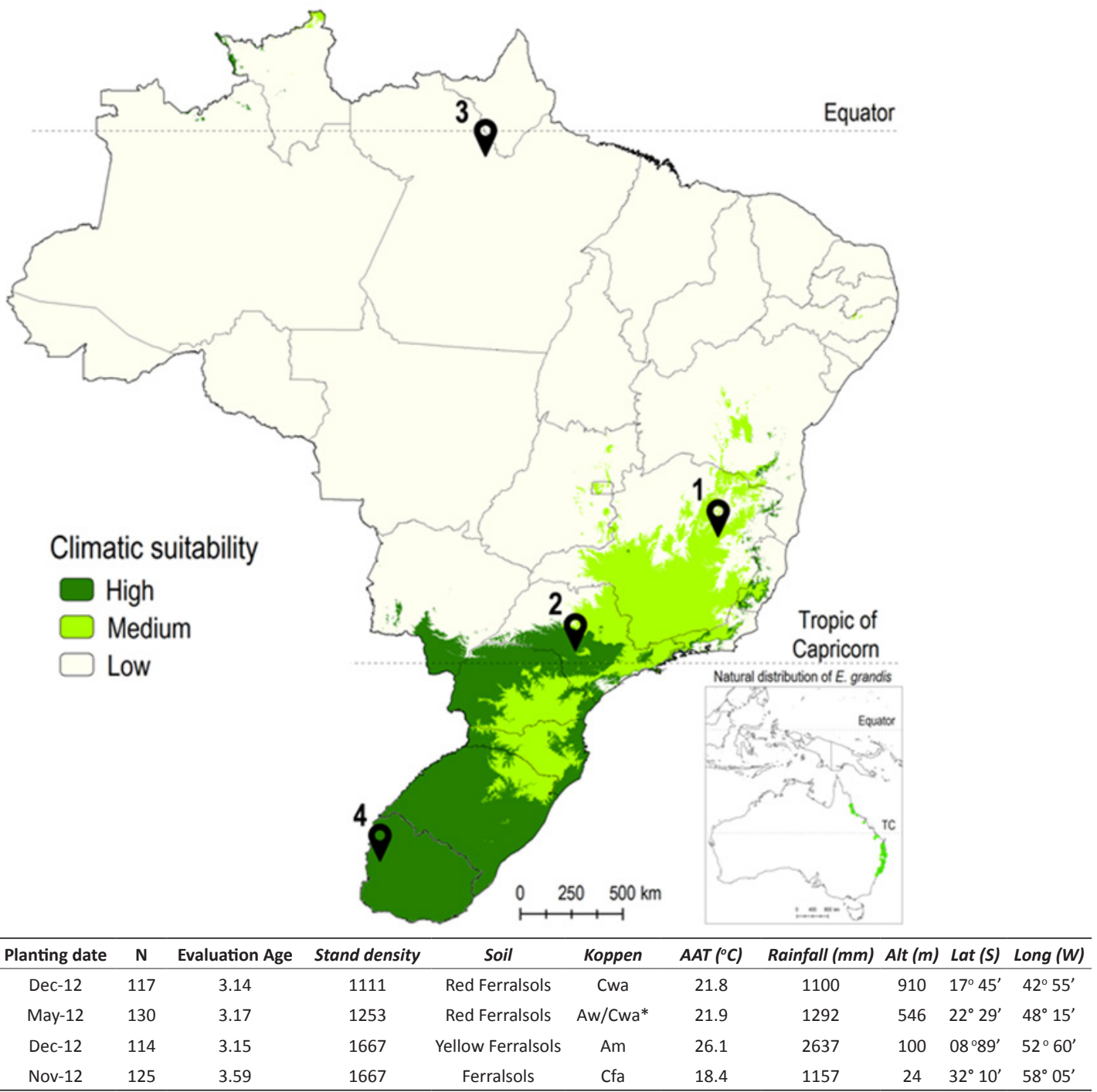

Figure 1. Map of the trials of the experimental network under distinct species suitability by climatic similarity with origin (adapted from Flores et al. 2016). N: number of open pollinated families; R: replication; AAT: annual average temperature; ${ }^{*}$ climate transition area; **Uruguay; Am: Tropical monsoon; Aw: Tropical with dry winter; Cfa: Humid Subtropical with hot summer; and Cwa: Humid subtropical with dry winters and hot summers. 
Individual analyses: $y=X r+Z a+W p+T s+e$,

Where the vectors are: $y$ - phenotypic observation; $r$ - replicate (assumed as fixed) added to the general average; other vectors assumed as random with a - additive genetic effect; $p$ - plot effect; $s$ - seed source effects; and e - error or residuals.

Inclusion of seed source to the models did not improve genetic parameter estimates and was therefore excluded from the joint analysis.

Joint analysis: $y=X r+Z g+W p+T i+e$,

Where the vectors are: $y=$ phenotypic observation; $r$ = replicate of all locations (assumed as fixed) added to the general average; other vectors assumed as random with $\mathrm{g}=$ genotypic effects; $\mathrm{p}=$ plot effects; $\mathrm{i}=$ family $\mathrm{x}$ environment interaction; and e = error or residuals.

As effects are associated to all assessment traits, unstructured variance-covariance matrices were estimated for each effect: $X, Z, W$ and $T$.

A deviance analysis was performed using the likelihood ratio test of family survival and DBH to check the significance of random effects. Variance component and genetic parameters were estimated using the REML/BLUP method.

The Harmonic Mean of Relative Performance of Genetic Values - HMRPGV (Spinelli et al. 2015, Resende 2016) was used to estimate stability and adaptability of DBH data. Stability corresponds to Harmonic Mean, which penalizes treatments with greater variance and adaptability refers to Relative Performance of family effects within each site, considering the mean of each trial. An advantage of the HMRPGV method is that it enables unbalanced datasets to be analyzed, where the lack of treatments (families) in one of the experiments does not require excluding that treatment from the joint analysis (Resende 2007).

The average coefficient of relatedness was considered to estimate genetic parameters in a mixed mating system, rather than half-sibs, as described in Tambarussi et al. (2018). An average coefficient of 0.16 self-fertilization was considered, according to Miranda et al. (2013).

\section{RESULTS AND DISCUSSION}

In this experimental network, we observed different productivity across the sites and Paulistânia-SP (MAI $=48.4 \mathrm{~m}^{3} \mathrm{ha}^{-1}$ $\left.\mathrm{y}^{-1}\right)$ as two-fold more productive than Itamarandiba-MG and Monte Dourado-PA. There was a three-fold range in survival (28\% at Monte Dourado-PA to 89\% in Paulistânia-SP-Table 2). Paulistânia-SP has Aw/Cwa climatic conditions (Koppen classification), considered optimal for E. grandis production (Garcia et al. 2014, Flores et al. 2016). The least productive

Table 2. Survival, height $(H)$, diameter at breast height $(\mathrm{DBH})$ and narrow sense $\mathrm{DBH}$ heritability $\left(\mathrm{DBH} \mathrm{h}^{2}\right)$ for each trial and genetic parameters in the joint analysis for five $E$. grandis family trials for $\mathrm{DBH}$

\begin{tabular}{|c|c|c|c|c|c|}
\hline Site & $\begin{array}{c}\text { Survival } \\
(\%)\end{array}$ & $\begin{array}{c}\mathbf{H} \\
(\mathrm{m})\end{array}$ & $\begin{array}{l}\text { DBH } \\
(\mathrm{cm})\end{array}$ & $\begin{array}{c}\text { MAI } \\
\left(\mathrm{m}^{3} \mathrm{ha}^{-1} \mathrm{y}^{-1}\right)\end{array}$ & DBH h ${ }^{2}$ \\
\hline \multicolumn{6}{|l|}{ Individual analyses } \\
\hline 1- Itamarandiba & 85 & 14.7 & 10.4 & 20.5 & $0.39+-0.05$ \\
\hline 2- Paulistânia & 89 & 18.0 & 13.1 & 48.4 & $0.19+-0.04$ \\
\hline 3- Monte Dourado & 28 & 15.1 & 11.0 & 20.6 & $0.25+-0.09$ \\
\hline 4- Paysandu & 65 & 16.8 & 9.1 & 41.1 & $0.26+-0.05$ \\
\hline \multicolumn{4}{|c|}{ Narrow sense heritability } & \multicolumn{2}{|r|}{$0.07+/-0.01$} \\
\hline \multicolumn{4}{|c|}{ Coefficient of determination for $\mathrm{G} \times \mathrm{E}$} & \multicolumn{2}{|r|}{0.08} \\
\hline \multicolumn{4}{|c|}{ Average heritability among families } & \multicolumn{2}{|r|}{0.70} \\
\hline \multicolumn{4}{|c|}{ Family correlation for $\mathrm{G} \times \mathrm{E}$} & \multicolumn{2}{|r|}{0.46} \\
\hline \multicolumn{4}{|c|}{ Coefficient of individual family variation } & \multicolumn{2}{|r|}{5.94} \\
\hline
\end{tabular}

For survival: no significate effect (deviance) was detected at $1 \%$ confidence level. 
sites were Itamarandiba-MG and Monte Dourado-PA for distinct reasons. The climate in Itamarandiba is Cwa (Koppen classification) and should have better conditions than Monte Dourado-PA (Am Koppen classification) for E. grandis growth (Figure 1). However, the rainfall in Itamarandiba during the trial period was nearly half of the historical average (2014 and 2015 rainfall $<600 \mathrm{~mm}$ ), resulting in moderate and prolonged water stress, known to reduce eucalypt productivity (Silva et al. 2016b, Gonçalves et al. 2017). On the other hand, in Monte Dourado, the disease Cylindrocladium leaf spot was observed. This disease resulted in high mortality of trees (72\%), which decreased productivity of the stand. This corroborates results of Rodas et al. (2005) that when E. grandis is grown as a pure species, it is not well adapted to the Am climatic condition in Monte Dourado, where high temperatures and humidity favor Cylindrocladium leaf disease. In this site, the disease attacks the trees since the first summer (wet and hot) and probably is the main mortality cause of susceptible material in the climatic conditions of the site, as discussed by Silva et al. (2019).

Even with high mortality, it was still possible to find some good trees in Monte Dourado-PA. More resources available (i.e. nutrients, water, and light) favored the remaining trees because of lower inter tree competition, which leveraged their growth (Wilson and Tilman 1993, Boyden et al. 2008). Therefore, some individuals from families 248 and 290, stood out from other trees and families in the site. Both families were well ranked in Harmonic Mean of Relative Performance of Genetic Values in the joint analysis (Family 248 is the $12^{\text {th }}$ and 290 is the $11^{\text {th }}$ ) having the largest trees of all sites. Based on their good overall performance and growth of some individuals under conditions favorable to Cylindrocladium leaf disease, both families may be the best option for hybridization (Denison and Kietzka 1993, Potts and Dungey 2004) with other species (e.g. E. pellita) for the production of elite hybrid trees for sites that are favorable to the disease. The hybridization program should result in the development of new genetic combinations that could improve biotic tolerance and improve stand productivity after adequate selection (Assis et al. 2005).

The selection of top 12 families ( $<10 \%$ of families) by the Harmonic Mean of Relative Performance of Genetic Values (HMRPVG) in the joint analysis across all sites resulted in a cohort of families that included at least four of the top ranked families in each site. The smallest number of top families was in Paysandu-UR, where three of the best families were not evaluated and the others were closely ranked. The largest number was observed in Itamarandiba-MG, where seven were in the 12 top families (Table 3 ) and the two other families were ranked $13^{\text {th }}$ and $14^{\text {th }}$. Some of the best families identified in HMRPVG were not planted across all sites due to seedling availability. In addition, few top families showed

Table 3. DBH ranking of stability and adaptability of top $12 \mathrm{E}$. grandis families based on Harmonic Mean of Relative Performance of Genetic Values across all sites and the actual family rank in each site; DBH Pairwise site coefficient of determination for GEI (c ${ }_{i}^{2}-a_{b o v e}$ diagonal) and pairwise family genotype correlation ( $r_{\mathrm{g}}$ - below diagonal) for Eucalyptus grandis

\begin{tabular}{|c|c|c|c|c|c|c|c|}
\hline Family & Stability and adaptability & Adaptability & Stability & ItamarandibaMG & Paulistânia SP & M Dourado PA & Paysandu UR \\
\hline 188 & 1 & 1 & 1 & 1 & 3 & $\mathrm{NI}$ & 1 \\
\hline 207 & 2 & 2 & 13 & 3 & 8 & 6 & $\mathrm{NI}$ \\
\hline 244 & 3 & 3 & 3 & 5 & 6 & 2 & 15 \\
\hline 241 & 4 & 4 & 9 & 8 & 1 & 25 & 4 \\
\hline 189 & 5 & 5 & 2 & 2 & 5 & 24 & 2 \\
\hline 206 & 6 & 6 & 10 & 11 & 15 & 4 & 13 \\
\hline 287 & 9 & 10 & 14 & 10 & 9 & 15 & 16 \\
\hline 300 & 10 & 9 & 35 & 48 & 12 & 8 & $\mathrm{NI}$ \\
\hline 290 & 11 & 11 & 47 & 43 & 13 & 16 & $\mathrm{NI}$ \\
\hline 248 & 12 & 12 & 21 & 13 & 31 & 31 & 6 \\
\hline \multicolumn{2}{|c|}{ Paysandu } & 0.77 & 0.72 & \multicolumn{2}{|c|}{0.24} & -- & 0.050 \\
\hline \multicolumn{2}{|c|}{ Average } & 0.54 & 0.52 & \multicolumn{2}{|c|}{0.10} & 0.58 & -- \\
\hline
\end{tabular}

$\mathrm{NI}-$ Not included due to problems in seedling production. 
poor rankings in specific sites. For example, family 233 is within the top $8^{\text {th }}$ families in the joint analysis; however, it displayed a different behavior from the other top performing families selected in joint analysis. Family 233 displayed a complex GEI with good adaptability (ranked $8^{\text {th }}$ ); however, with not so good stability (ranked $15^{\text {th }}$ ). This was attributed to the poor performance of this family in Itamarandiba-MG (ranked 31 $1^{\text {st }}$ ) and Paulistânia-SP (ranked $59^{\text {th }}$ ), to the excellent performance in Monte Dourado-PA (ranked $1^{\text {st }}$ ) and intermediary performance in Paysandu-UR (ranked $14^{\text {th }}$ ). These different behaviors may be attributed to the tolerance of the family to Cylindrocladium leaf spot.

In the individual and joint deviance analyses, no significant effects and no family correlation between sites was observed for survival across the four sites. On the other hand, DBH heritability between families and family by environment correlation were 0.70 and 0.46 , respectively, indicating strong genetic control with families and moderate control for productivity across site stability.

The absence of significant differences between seed sources, although selected under different environmental conditions in Argentina, Brazil and Uruguay, could in part could be explained due to greater variation within than between seed sources. Other authors (Marcó and White 2002, Harrand et al. 2009) have reported this variation within the seed source. However, the seedlots were obtained from mother trees selected from breeding populations grown under subtropical conditions, where provenances from the Coffs Harbor region generally exhibit better performance (Ferreira 2015). Although they are from different breeding programs, all seed sources may be genetically similar (all Coffs Harbour derived). If other provenances (e.g. Atherton Tableland sources) of $E$. grandis were tested, more interprovenance variation would be expected (Eldridge et al. 1993, Bandara and Arnold 2017). Another issue is the outcrossing level between seed sources. Burgess et al. (1996) conducted a study on E. grandis in Coffs Harbour and observed that outcrossing levels strongly influenced growth traits and differences between provenances were not significant.

DBH heritability within each site range from 0.19 to 0.39 is considered intermediate for this growth character. This range is similar to improved E. urophylla families evaluated across ten sites in Brazil (Silva et al. 2019), with a range from 0.09 to 0.29 , considering mixed mating. The highest DBH heritability was obtained in Itamarandiba-MG, indicating lower environmental effects on phenotypic variation. This may be attributed to moderate and prolonged water stress that occurred in this site during the trial.

The narrow sense heritability in the joint analysis was low, due to the large environmental variation across the sites. The intermediary genetic correlations across sites and the results of the sites pairwise correlation indicated that simple GEI were occurring between three trials; however, one site (Monte Dourado-PA) showed a low coefficient of determination for GEI (Table 3). The lowest pairwise genetic correlation between sites was found in Monte Dourado-PA, an area of Am climatic conditions. Monte Dourado-PA showed a coefficient of determination lower than 0.05 in pairwise with Itamarandiba-MG and Paulistânia-SP. However, despite complex GEI, the selection of some families for all sites was possible. Similar to the findings for Eucalyptus urophylla, which was planted across five sites in Brazil, Pupin et al. (2015) found for E. urophylla that it was possible to select families in a site with intermediate climatic condition, which showed the highest genetic correlation with the other trials.

This suggests even that a broadly based breeding program could be used to select elite families for deployment across all of the environments tested. Genetic by environmental interaction generates a strong effect on specific sites and stratification of environments is necessary. In addition, the lack of genetic variation between the five sources for growth and survival traits may imply that infusions of $E$. grandis material from other populations (e.g. Atherton) could be beneficial to future development of this species.

\section{CONCLUSION}

Few families were the most productive and stable across the sites with contrasting environments in Uruguay and Brazil. These families were selected due to lower $\mathrm{GEI}$, where the families selected were the most adaptable and stable.

Selection of elite families in intermediate climatic growing conditions allows selection of a suitable germplasm across the diverse range of climatic conditions evaluated. Nevertheless, attention should also be given to families that perform well in specific climatic or site conditions to ensure the use of opportunities to select species for pest and disease or adaptation to facilitate genetic gain in the improvement of pure species and development of new hybrid clones. 


\section{REFERENCES}

Acquaah G (2007) Principles of plant genetics and breeding. Blackwell Publishing, Oxford, 568p.

Alvares CA, Sentelhas PC, Mattos EM, Miranda AC, Moraes WB, Silva PHM, Furtado EL and Stape JL (2016) Climatic favourability zones for Eucalyptus rust in Brazil. Forest Pathology 47: 1-17.

Assis T, Warburton P and Harwood C (2005) Artificially induced protogyny: an advance in the controlled pollination of Eucalyptus. Australian Forestry 68: 27-33.

Bandara KMA and Arnold RJ (2017) Genetic variation of growth and log end-splitting in second-generation Eucalyptus grandis in Sri Lanka. Australian Forestry 80: 264-271.

Boland DJ, Brooker MIH, Chippendale GM, Hall N, Hyland BPM, Johnson RD, Kleinig DA, McDonald MW and Turner JD (2006) Forest tree of Australia. CSIRO Publishing, Melbourne, 768p.

Boyden S, Binkley D and Stape JL (2008) Competition among Eucalyptus trees depends on genetic variation and resource supply. Ecology 89: 2850-2859.

Brawner JT, Lee DJ and Hardner CN (2011) Relationships between early growth and Quambalaria shoot blight tolerance in Corymbia citriodora progeny trials established in Queensland Australia. Tree Genetics \& Genomes 7: 759-772.

Brawner JT, Lee DJ, Meder R, Almeida AC and Dieters MJ (2013) Classifying genotype by environment interactions for targeted germplasm deployment with a focus on Eucalyptus. Euphytica 191: 403-414.

Brooker MIH and Kleinig DA (2004) Field guide to eucalypts northern Australia. Bloomings Books, Melbourne, 383p.

Burgess IP, Williams ER, Bell JC, Harwood CE and Owen JV (1996) The effect of outcrossing rate on the growth of selected families of Eucalyptus grandis. Silvae Genetica 45: 97-101.

Campoe OC, Munhoz JSB, Alvares CA, Carneiro RL, Mattos EM, Ferez APC and Stape JL (2016) Meteorological seasonality affecting individual tree growth in forest plantations in Brazil. Forest Ecology Management 380: 149-160.

Conradie E, Swart WJ and Wingfield MJ (1992) Susceptibility of Eucalyptus grandis to Cryphonectria cubensis. European Journal of Forest Pathology 22: 312-315.

Denison NP and Kietzka JE (1993) The use and importance of hybrid intensive forestry in South Africa. South Africa Forest Journal 165: 55-60.

Eldridge K, Davidson J, Harwood C and van Wyk G (1993) Eucalypt domestication and breeding. Clarendon Press, Oxford, 312p.

Ferreira M (2015) A aventura dos eucaliptos. In Schumacher MV and Viera M (eds) Silvicultura do eucalipto no Brasil. UFSM, Santa Maria, p.13-48.

Flores TB, Alvares CA, Souza VC and Stape JL (2016) Eucalyptus in Brazil: climatic zoning and guide for identification. IPEF, Piracicaba, 447p.
Gapare WJ, Barnes RD, Gwaze DP and Nyoka BI (2003) Genetic improvement of Eucalyptus grandis using breeding seedling orchards and multiple population breeding strategy in Zimbabwe. South Africa Forest Journal 197: 13-19.

Garcia LG, Ferraz SFB, Alvares CA, Ferraz KMPMB and Higa RCV (2014) Modeling suitable climate for Eucalyptus grandis under future climates scenarios in Brazil. Scientia Forestalis 42: 503-511.

Gonçalves JLM, Alvares CA, Rocha JHT, Brandani CB and Hakamada RE (2017) Eucalypt plantation management in regions with water stress. Southern Forest: Journal Forest Science 79: 169-183.

Harrand L, Vargas Hernandez JJ, Lopez Upton J and Ramirez Valverde G (2009) Genetic parameters of growth traits and wood density in Eucalyptus grandis progenies planted in Argentina. Silvae Genetica 58: 11-19.

Harwood C (2011) New introductions - doing it right. In J Walker (ed) Proceedings of the workshop of developing a eucalypt resource. Learning from Australia and elsewhere. University of Canterbury, Christchurch, p. 125-136.

Jurskis V (2005) Eucalypt decline in Australia and a general concept of tree decline and dieback. Forest Ecology Management 215: 1-20.

Malosetti M, Ribaut J-M van Eeuwijk F (2013) The statistical analysis of multi-environment data: modeling genotype-by-environment interaction and its genetic basis. Frontiers in Physiology 4: 44.

Marcó MA and White TL (2002) Genetic parameter estimates and genetic gains for Eucalyptus grandis and E. dunnii in Argentina. Forest Genetics 9: 205-215.

Miranda AC, Moraes MLT, Tambarussi EV, Furtado EL, Mori ES, Silva PHM and Sebbenn AM (2013) Heritability for resistance to Puccinia psidii winter rust in Eucalyptus grandis hill ex maiden in southwestern Brazil. Tree Genetics \& Genomes 9: 321-329.

Potts BM and Dungey HS (2004) Hybridization of eucalyptus: key issues for breeders and geneticists. New Forest 27: 115-138.

Pupin S, Santos AVDA, Zaruma DUG, Miranda AC, Silva PHM, Marino CL, Sebbenn AM and Moraes MLT (2015) Productivity stability and adaptability in open pollination progenies of Eucalyptus urophylla S.T. Blake. Scientia Forestalis 43: 127-134.

Resende MDV (2016) Software Selegen-REML/BLUP: a useful tool for plant breeding. Crop Breeding and Applied Biotechnology 16: 330-339.

Resende MDV (2007) Matemática e estatística na análise de experimentos e no melhoramento genético. Embrapa, Colombo, 561p.

Rodas CA, Lombard L, Gryzenhoinf M, Slippers B and Wingfield MJ (2005) Cylindrocladium blight of Eucalyptus grandis in Colombia. Australian Plant Pathology 34: 143-149.

Silva PHM, Miranda AC, Moraes MLT, Furtado EL, Stape JL, Alvares CA, Sentelhas PS, Mori ES and Sebbenn AM (2013) Selecting for rust (Puccinia psidii) resistance in Eucalyptus grandis in São Paulo state Brazil. Forest Ecology Management 303: 91-97. 


\section{PHM Silva et al.}

Silva PHM, Bouillet J-P and Paula RC (2016a) Assessing the invasive potential of commercial Eucalyptus species in Brazil: Germination and early establishment. Forest Ecology Management 374: 129-135.

Silva PHM, Campoe OC, Paula RC and Lee DJ (2016b) Seedling growth and physiological responses of sixteen eucalypt taxa under controlled water regime. Forests 7: 1-13.

Silva PHM, Brune A, Alvares CA, Amaral W, Teixeira MLT, Grattapaglia D and Paula RC (2019) Selecting for stable and productive families of Eucalyptus urophylla S.T. Blake across a country wide range of climates in Brazil. Canadian Journal of Forest Research 49: 87-95.

Spinelli VM, Dias LAS, Rocha RB and Resende MDV (2015) Estimates of genetic parameters with selection within and between half-sib families of Jatropha curcas L. Industrial Crops and Products 69: 355-361.
Tambarussi EV, Pereira FB, Silva PHM, Lee D and Bush D (2018) Are tree breeders properly predicting genetic gain? A case study involving Corymbia species. Euphytica 214: 150-161.

Van Buijtenen JP (1992) Fundamental genetic principles. In Fins L, Friedman ST and Brotschol JV (eds) Handbook of quantitative forest genetics. Forestry sciences. Springer, Dordrecht, p. 29-68.

van Wyk G (1976) Early growth results in a diallel progeny test of Eucalyptus grandis (Hill) Maiden. I. A field study. Silvae Genetica 25: 126-132.

Wilson SD and Tilman D (1993) Plant competition and resource availability in response to disturbance and fertilization. Ecology 74: 599-611.

Wingfield MJ, Slippers B, Hurley BP, Coutinho TA, Wingfield BD and Roux $\mathrm{J}$ (2008) Eucalypt pests and diseases: growing threats to plantation productivity. South Forest Journal of Forest Science 70: 139-144. 